\title{
Avaliação Ambiental de Sistema Simplificado de Esgotos
}

\author{
Lauren Morais da Silva \\ Escola Agrícola Federal do Alegrete - RS \\ laurendasilva@terra.com.br \\ Geraldo Lopes da Silveira \\ Departamento de Hidráulica e Saneamento/CT/UFSM \\ ger_ufsm@terra.com.br
}

Recebido: 17/12/03 - revisado: 10/03/05 - aceito: 19/05/06

\section{RESUMO}

Os serviços de esgotos para pequenas coletividades devem estar associados a um baixo custo de implantação e de operação e devem prever que a disposição final dos efluentes não cause poluição aos mananciais. Apresenta-se, neste artigo, um estudo do impacto no meio, causado pelo uso de sistema simplificado de esgotos mediante a avaliação da eficiência sanitária em conjunto com a avaliação hidrológica relativo à alteração quali-quantitativo dos escoamentos do corpo receptor. Avaliou-se o sistema Cynamon aplicado a uma comunidade de padrão aquisitivo baixo, com população em torno de 2.000 pessoas, no ambiente de pequena bacia hidrográfica, com área de drenagem de 9,6 km2 na seção de recepção dos efluentes líquidos. Em termos sanitários, obteve-se $74 \%$ de remoção de DBO e de sólidos totais, resultado considerado bom, e $90 \%$ para os coliformes, resultado considerado muito ruim. Em termos hidrológicos, mesmo para a situação desfavorável de pequena bacia, com a ocorrência de vazões específicas medianas e minimas menores em relação a bacias maiores, as cargas efluídas pelo sistema não provocaram degradação de qualidade no escoamento do corpo receptor. Opta-se pela aplicabilidade do sistema, mesmo na situação desfavorável de pequenas vazões no corpo receptor e recomenda-se um polimento final ao efluente líquido por meio de lagoas de maturação para maior eficiência na remoção dos coliformes.

Palavras-chave: impacto hidrológico, monitoramento, saneamento ambiental

\section{INTRODUÇÃO}

A grande carência de sistemas de esgotos em núcleos isolados é realidade notória em todo o território nacional, segundo se depreende dos dados do último censo IBGE, 2000. Os núcleos isolados podem compreender conglomerados rurais ou pequenos municípios, além de bairros ou distritos de municípios maiores. $\mathrm{O}$ fato de serem isolados ou distantes de grandes concentrados populacionais, na maioria das vezes, os privam de possuir sistemas de esgotos por dificuldades de ordem econômica e financeira de implantação de sistemas convencionais.

Os sistemas simplificados de tratamento de esgotos, normalmente, estão vinculados a processos não aerados. Eles podem se constituir de lagoas de estabilização ou de tanques sépticos acompanhados de filtros anaeróbios ou, ainda, de sistemas de disposição no solo. Von Sperling (1996) entende que, usualmente, a simplicidade conceitual está relacionada a processos mais naturais, menos mecanizados e mais econômicos de implantar-se.

Segundo o PROSAB (2002), o estágio atual dos serviços de tratamento de esgotos, no Brasil, exige o imediato desenvolvimento de sistemas de tratamento e disposição final de águas residuárias que apresentem ótima relação custo-benefício, simplicidade e rapidez de construção e operação e também garantam a não poluição das águas de abastecimento.

Ainda, conforme Andrade Neto (1997), apesar da já expressiva experiência brasileira com sistemas simples, são poucos os dados disponíveis e confiáveis sobre a eficiência deles.

Em da face disso, o objetivo do presente artigo é avaliar a aplicabilidade de um sistema simpli- 
ficado de esgotamento sanitário em pequena bacia, a partir de dados medidos diretamente no local, tanto no sistema como no corpo receptor.

Vale ressaltar que muitas vezes, os sistemas de esgotos podem ter uma eficiência relativa aceitável e o corpo receptor não possuir uma vazão de diluição adequada. Por isso surge a necessidade de uma avaliação de forma integrada, que considere o sistema inserido no meio onde se desenvolve, mais precisamente, que considere a bacia hidrográfica.

\section{MATERIAL E MÉTODOS}

\section{O sistema Cynamon}

O sistema desenvolvido pelo Prof. Szachna Eliasz Cynamon da ENSP/FIOCRUZ é o "Sistema não convencional de esgoto sanitário a custo reduzido para pequenas coletividades e áreas periféricas". Este sistema consiste na utilização de um tanque séptico em cada residência no qual ocorre o tratamento primário do esgoto. Após, o esgoto é conduzindo à rede coletora de pequeno diâmetro, que possui declividade reduzida e substitui os poços de visita por tubos de inspeção e limpeza. Conforme previsão de Cynamon (1986), essas alterações na rede coletora permitem uma redução de custo total de $52 \%$ a $69 \%$.

O tratamento final do esgoto sanitário é realizado na Estação de tratamento de esgoto (ETE), com tratamento secundário num sistema simplificado (sem mecanização). Esse se compõe de um filtro anaeróbio (com enchimento em brita $\mathrm{n} 4 \mathrm{com}$ fluxo ascendente/descendente em três câmaras) seguido de um filtro de areia grossa (polimento) e com o lançamento final do efluente no corpo receptor. O lodo gerado pelos tanques sépticos é recolhido anualmente e disposto em leito de secagem individual, junto aos tanques sépticos.

O sistema, objeto deste estudo, que tem como referencial o sistema concebido por Cynamon, já se encontra implantado em uma parte da Vila São Luiz, no município de Restinga Seca/RS. Projetado para uma população de 1.827 pessoas, corresponde a uma densidade demográfica de 69,6 hab/hectare.

Atualmente, a vila possui 1.141 habitantes, em 301 domicílios, sendo as economias de padrão simples em núcleo habitacional popular.

O sistema implantado se constitui de tanques sépticos cilíndricos de câmara única, conforme a Figura 1. Os tanques são dimensionados segundo a
NBR 7229/93, para o padrão de residência unifamiliar (5 pessoas), com metragem de 1,10 metros de diâmetro e 1,95 metros de altura, posicionados em frente à unidade residencial, junto ao parâmento público da calçada, de modo a facilitar a manutenção por meio de caminhões limpa-fossa.

Após a detenção do esgoto pelo tanque, ele passa por um processo inicial de estabilização com decantação do lodo, sendo conduzido à fase líquida do processo por rede PVC de pequeno diâmetro (inicial: $40 \mathrm{~mm}$, final: $150 \mathrm{~mm}$ ). Esta rede desenvolvese sob a calçada, recolhendo o efluente de todas as economias e o conjunto delas chega ao filtro anaeróbio.

Uma vantagem desse tipo de sistema, quando comparado ao processo construtivo da rede convencional, é a diminuição dos transtornos provocados à comunidade. A rede convencional abre escavações localizadas na pista de rolamento com o diâmetro maior para a tubulação, porque nesse caso, conduz-se esgoto bruto. Na Figura 1, visualiza-se o processo construtivo da rede que caracteriza uma das vantagens do sistema.

A fase final do processo de tratamento do esgoto consiste na passagem do efluente líquido recolhido dos tanques sépticos de todas as economias, através do filtro anaeróbio.

No sistema implantado, adotou-se o leito de secagem coletivo junto a ETE, de modo que a drenagem do seu efluente líquido sofra tratamento no filtro, diferenciando-se do sistema proposto pelo Prof. Cynamon. A adoção dessa medida visa garantir um controle mais rigoroso da prefeitura sobre tal sistema.

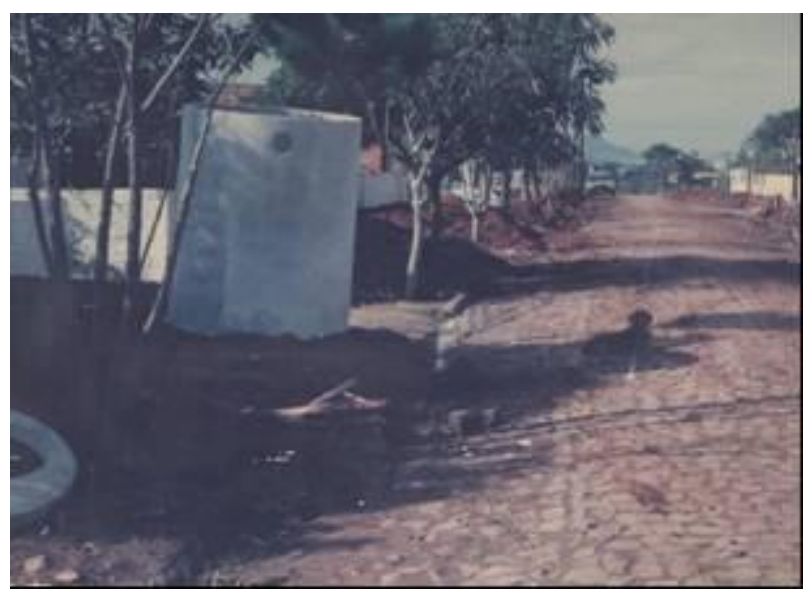

Figura 1 - Execução da rede coletora 
Tabela 1 - Características fisiográficas da bacia da Sanga da Restinga

\begin{tabular}{ll|ll}
\hline Item & Descrição & Item & Descrição \\
\hline Área & $9,2 \mathrm{~km}^{2}$ & Declividade média bacia & $0,1008 \mathrm{~m} / \mathrm{m}$ \\
Perímetro da bacia & $13,7160 \mathrm{~km}$ & $\begin{array}{l}\text { Declividade média simples } \\
\text { do rio }\end{array}$ & $013 \mathrm{~m} / \mathrm{m}$ \\
Declividade média racional & $0,0091 \mathrm{~m} / \mathrm{m}$ \\
Coeficiente de compacidade & 1,26 & Declividade média constante & $0,010 \mathrm{~m} / \mathrm{m}$ \\
Fator de forma & 0,25 & Elevação média da bacia & $89,81 \mathrm{~m}$ \\
Comp. do rio principal & $6,089 \mathrm{~km}$ & $94,52 \mathrm{~m}$ \\
Rede de drenagem & $14.706,15 \mathrm{~m}$ & Altitude mediana & $90 \mathrm{~m}$ \\
Densidade de drenagem & $1,60 \mathrm{~km} / \mathrm{km}^{2}$ & Altitude média & \\
\hline Item & Descrição & & \\
\hline Rocha & Formação São Pedro & \\
Solo predominante & Solo podzólico vermelho amarelo de textura média \\
Relevo & Ondulado formando coxilhas alongadas & \\
Vegetação & Predomina campos e gramíneas \\
Clima & De acordo com Koppen, clima temperado chuvoso e quente, do tipo Cfa. \\
\hline
\end{tabular}

\section{O corpo receptor e a bacia hidrográfica}

O corpo receptor (Sanga da Restinga) que recebe as efluências do filtro anaeróbio é caracterizado pela bacia hidrográfica de montante que define a variabilidade das vazões de diluição dos efluentes, em conseqüência do ciclo hidrológico.

A bacia hidrográfica, definida pela seção no ponto de lançamento das efluências do sistema, possui uma área de aproximadamente $10 \mathrm{~km}^{2}$ (Figura 2). É uma bacia vertente do curso médio do Rio Vacacaí-Mirim, afluente do Rio Jacuí, formador principal da bacia do Guaíba, que desemboca na capital do Estado, Porto Alegre.

Até a seção de lançamento dos efluentes, a bacia possui ocupação predominantemente rural (em torno de 96\%) já no local de ocupação urbana, recebe contribuição de esgoto doméstico pelas duas margems. Pela direita, recebe os efluentes do sistema em avaliação, referente à Vila São Luiz; pela margem esquerda, os da Vila Pelizaro, com pequena população, (aproximadamente de 280 pessoas). Essa vila utiliza, para o tratamento dos esgotos, o sistema de tanques sépticos e sumidouro, ou poço negro. Em alguns casos, o lançamento é direto em valas a céu aberto (futuramente, deve receber um sistema de coleta e de tratamento semelhante ao empregado na Vila São Luiz). Na Tabela 1, constam as características físicas da bacia, corpo receptor dos efluentes.

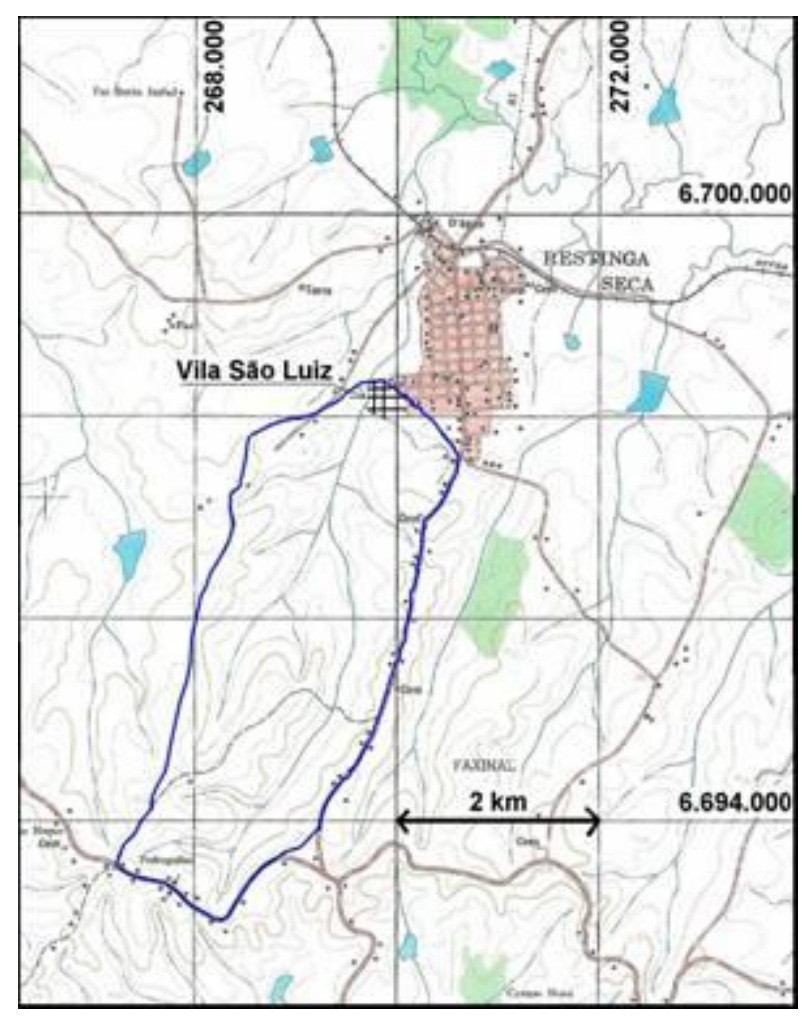

Figura 2 - Delimitação da bacia hidrográfica na seção da ETE, coordenadas UTM - Carta topográfica de Restinga Seca $/$ SH. 


\section{Avaliação Ambiental}

Neste estudo, para a avaliação ambiental, considerou-se de forma conjunta a eficiência da ETE (avaliação sanitária) e os reflexos produzidos pelo lançamento de efluências no corpo receptor (avaliação hidrológica).

Foram estabelecidos cinco pontos de controle para os escoamentos, conforme a Figura 3. Os pontos PC1 e PC2 são pontos de controle na ETE; já os pontos PC3, PC4 e PC5 são pontos de controle hidrológico no corpo receptor.

O PC1 localiza-se na entrada do filtro anaeróbio e recebe os efluentes dos tanques sépticos; o PC2 localiza-se na saída do filtro e recebe seus efluentes antes de lança-los no corpo receptor.

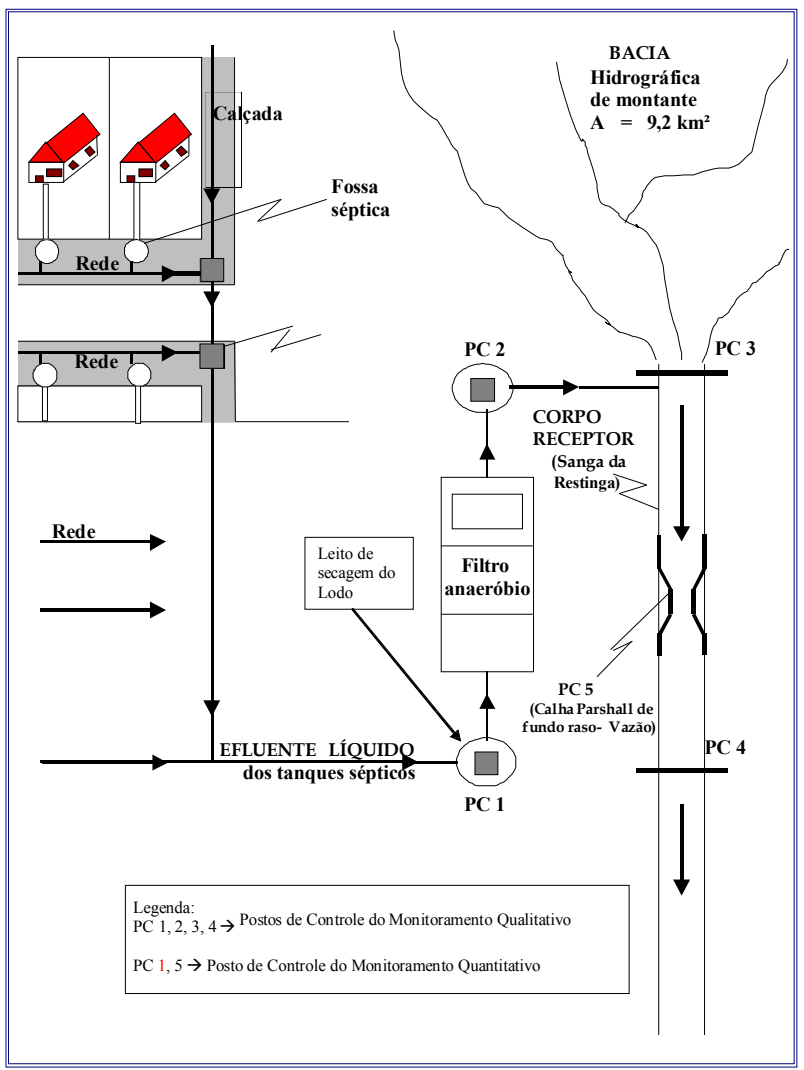

Figura 3 - Sistema de monitoramento da ETE e hidrológico.

Os pontos de controle PC1, PC2, PC3 e PC4 servem de ponto de coleta para as amostras de esgoto e de água (monitoramento qualitativo) e o PC5 permite o monitoramento das vazões na Sanga da Restinga (monitoramento quantitativo). O PC1 também é utilizado para o monitoramento das vazões de contribuição do sistema de esgoto ao corpo receptor.

Em face disso descreve-se a metodologia com as etapas de monitoramento e de avaliação propriamente dita com a seguinte seqüência:

a) monitoramento hidrológico,

b) monitoramento sanitário (na ETE),

c) avaliação hidrológica e;

d) avaliação sanitária (da eficiência da ETE).

\section{(a) Monitoramento hidrológico}

Com base na experiência de Silveira (1997), implantou-se uma calha Parshall, construída em estrutura de concreto armado sobre gabiões, para medir vazões de medianas a mínimas, que se localiza 30 metros à jusante do ponto de lançamento dos esgotos, sob o pontilhão que une a Vila São Luiz à Vila Pelizaro (Figura 4).

A escolha do local deve-se à facilidade de construção; pois, nesta seção define-se através do pontilhão, um canal de aproximação.

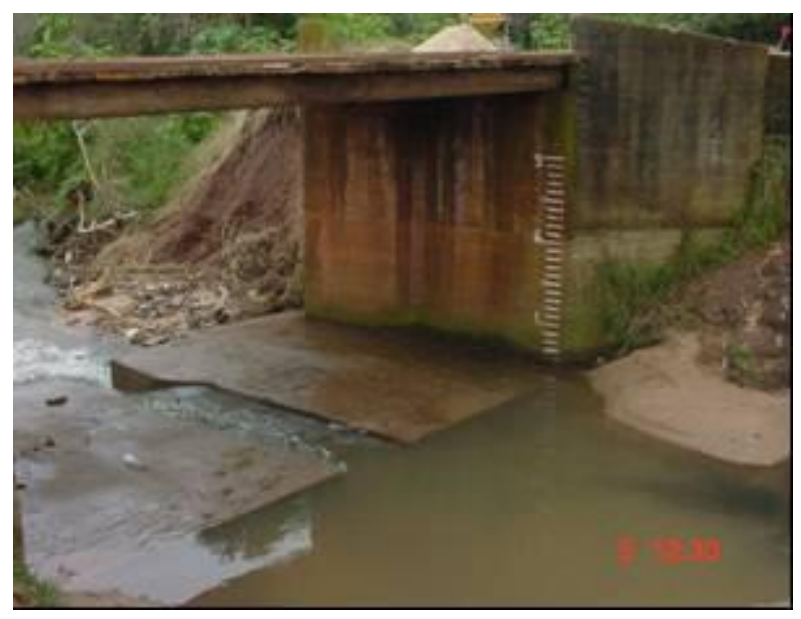

Figura 4 - Calha Parshal na Sanga da Restinga

A calha Parshall implantada (PC5) possui um comprimento de $180 \mathrm{~cm}$, uma largura da garganta (estreitamento da seção de escoamento) de 60 $\mathrm{cm}$ e uma altura de entrada de $50 \mathrm{~cm}$. Ela permite avaliar vazões até $28,20 \mathrm{~m}^{3} / \mathrm{min}$, sem que ocorra transbordamento.

No caso de transbordamento da calha é possível a realização da medição do nível, já que se encontra marcado de $5 \mathrm{em} 5 \mathrm{~cm}$ em uma régua na 
parede de concreto do pontilhão, que tem como ponto zero o fundo da calha na seção em que se realiza a medição do nível.

\section{(b) Monitoramento da ETE}

O PC1 foi construído com o objetivo de constituir-se em caixa coletora para analisar a qualidade da água e para medir as vazões produzidas pelo sistema. Esse possui tampa de concreto, construída em alvenaria rebocada, com as seguintes dimensões $0,83 \mathrm{~m} \times 0,83 \mathrm{~m}$ por $1,80 \mathrm{~m}$ de altura. Nessa tampa está fixada uma régua metálica (com marcação em relevo e espaçamento de $30 \mathrm{~cm}$ ) para leitura do nível e também está fixado um tubo de drenagem de $100 \mathrm{~mm}$.

Com o esvaziamento da caixa coletora e posterior fechamento do tubo de drenagem, podese cronometrar o tempo de enchimento. Dessa forma, pode-se calcular a vazão do sistema, além da coleta de amostra das efluências dos tanques sépticos que adentram no filtro anaeróbio.

O PC2 se constitui de uma caixa do próprio filtro, localizada após a última etapa de filtragem, ou seja, é um filtro de areia, com tampa em concreto $(60 \times 60 \mathrm{~cm})$, do qual se faz a retirada de amostras das efluências do filtro anaeróbio.

Na Figura 5, visualizam-se os pontos de controle PC1 e PC2 na ETE.

O monitoramento permite avaliar a eficiência, em temos sanitários, do sistema de tratamento de esgotos.

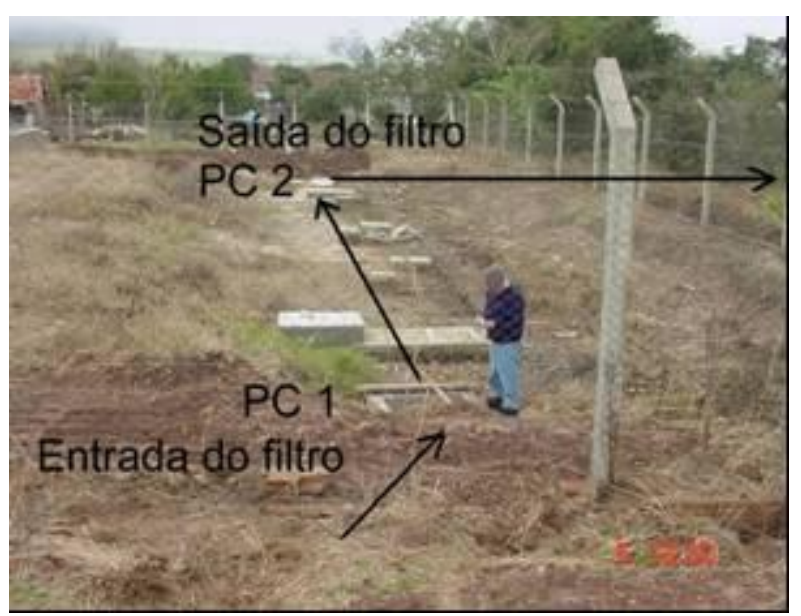

Figura 5 - Pontos de controle na ETE
O PC3 é o ponto de coleta de amostras, localizado no corpo receptor, 15 metros à montante do ponto de lançamento dos efluentes do filtro anaeróbio.

O PC4 é o ponto de coleta de amostras localizado no corpo receptor, 15 metros à jusante do ponto de lançamento dos efluentes do filtro anaeróbio.

Na Figura 6, visualizam-se os pontos de controle PC3 e PC4 na Sanga da Restinga.

Os pontos de controle no corpo receptor permitiram, pelo conhecimento quali-quantitativo do corpo receptor, avaliar o impacto do lançamento de efluentes e realizar simulações da capacidade de assimilação da carga orgânica lançada pela fonte poluente e o efeito da diluição desta carga frente a variabilidade das vazões que ocorrem no riacho.

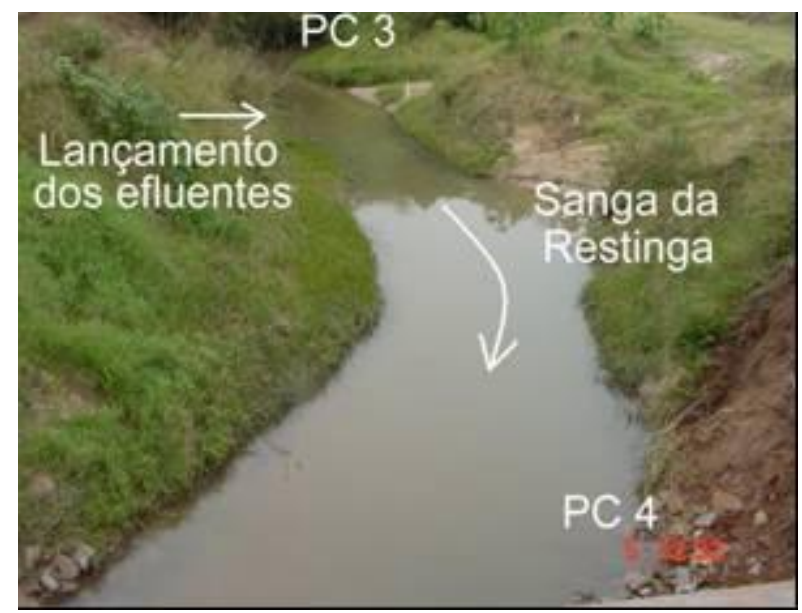

Figura 6 - Pontos de controle no riacho.

\section{c) Avaliação hidrológica}

A avaliação hidrológica envolve a qualidade (concentração) e a quantidade (vazão) e procura identificar o efeito de diluição das cargas geradas pela ETE no espectro de variabilidade das vazões na bacia hidrográfica.

No momento da coleta das amostras de esgoto sanitário mede-se a vazão na ETE, na caixa coletora em PC1, e, na bacia hidrográfica, junto à calha parshal.

A partir daí, há possibilidade de conhecer-se a carga poluidora concomitante presente no sistema de esgoto sanitário e no corpo receptor, multiplicando-se a concentração pela vazão. 
$\mathrm{Na}$ avaliação hidrológica, procura-se verificar o efeito do lançamento dos efluentes da ETE no corpo receptor, por meio de três formas de avaliação.

Inicialmente, faz-se uma avaliação global da qualidade da água do corpo receptor, antes e após o lançamento dos efluentes, com base no índice de qualidade de água (IQA) proposto por National Sanitation Foundation (NSF) em 1970 e adaptado para 8 parâmetros por COMITESINOS (1990, 1993). Os pesos dos parâmetros são os seguintes: Oxigênio Dissolvido: 0,19; Coliformes fecais: 0,17; pH: 0,13; Demanda Bioquímica de Oxigênio: 0,11; Fosfato Total: 0,11; Nitrato: 0,11; Turbidez 0,09; Sólidos Totais: 0,09. Dessa forma, é possível acompanhar a evolução da qualidade de água do corpo receptor, resumindo uma série de parâmetros num único número (Gastaldini \& Teixeira, 2001).

A segunda forma de avaliar o impacto hidrológico consiste em avaliar as cargas produzidas pela ETE, em conjunto com as já transportadas pelo corpo receptor nas proximidades das efluências da ETE. Avalia-se a diluição das cargas ante as diferentes vazões da curva de permanência da sanga da restinga, da vazão mediana $Q_{50 \%}$ até a vazão mínima $\mathrm{Q}_{95 \%}$.

$\mathrm{Na}$ última forma de avaliação, é feita uma simulação da capacidade de autodepuração do corpo receptor, das vazões medianas a mínimas, utilizando-se o modelo simplificado de Streeter-Phelps, para a situação de operação atual e para a situação em que o sistema opere nos limites máximos da Licença de Operação, concedido pelo órgão ambiental do RS, para o licenciamento da ETE. A importância da compreensão do fenômeno da autodepuração e da sua quantificação tem como objetivo utilizar a máxima capacidade de assimilação dos rios e, também, impedir o lançamento de despejo acima do que possa suportar o corpo d'água (Von Sperling, 1996).

\section{(d) Avaliação da eficiência da ETE}

Adotou-se a freqüência mensal para a coleta das amostras, que se realizou no período da manhã, em virtude da necessidade de conservação e transporte até os laboratórios. Os parâmetros monitorados foram: temperatura do ar; temperatura do líquido (esgoto ou água); potencial hidrogeniônico $(\mathrm{pH})$; oxigênio dissolvido (OD); condutividade elétrica; demanda química de oxigênio (DQO); demanda bioquímica de oxigênio (DBO5,20); sólidos totais (ST); sólidos totais suspensos (STS); sólidos totais dissolvidos (STD); sólidos sedimentáveis (SSED); cloretos; alcalinidade; acidez; turbidez; óleos e graxas; coliformes totais e coliformes fecais.

A coleta, a preservação e o transporte das amostras foram realizados conforme preconizado no "Guia de coleta e preservação de amostras de água", da CETESB (1987). A determinação analítica dos parâmetros de qualidade das amostras de esgoto sanitário e de água é realizada de acordo com as especificações contidas no "Standard Methods for the Examination of Water and Wastewater", 19 ${ }^{\mathrm{a}}$ edição (1995). Os parâmetros de qualidade são determinados tanto em campo quanto em laboratório.

Por causa da dificuldade de realizar-se a coleta de amostras na entrada dos tanques sépticos, adotou-se, no presente trabalho, pela concentração do esgoto bruto (Conc.PC0), a partir de valores típicos da literatura, conforme a Tabela 2, e determinam-se os valores desses parâmetros nas duas etapas do processo, isto é, na entrada e na saída do filtro anaeróbio.

Tabela 2 - Concentração média do esgoto bruto

\begin{tabular}{ll}
\hline Parâmetro & Concentração \\
\hline DBO & $350 \mathrm{mg} / \mathrm{L}$ \\
DQO & $700 \mathrm{mg} / \mathrm{L}$ \\
ST & $1100 \mathrm{mg} / \mathrm{L}$ \\
STS & $400 \mathrm{mg} / \mathrm{L}$ \\
CF & $10^{7} \mathrm{org} / 100 \mathrm{~mL}$ \\
\hline
\end{tabular}

O ponto de controle PC1 fornece a concentração PC1 (Conc.PC1), que corresponde à concentração do efluente dos tanques sépticos que adentram no filtro anaeróbio. A concentração de PC1, em conjunto com a concentração do esgoto bruto (Conc.PC0), possibilita uma avaliação da eficiência do tratamento primário (tanques sépticos).

$\mathrm{O}$ ponto de controle PC2 fornece a concentração PC2 (Conc.PC2), que corresponde à concentração do efluente do filtro anaeróbio antes do lançamento no corpo receptor e permite avaliar a eficiência do tratamento secundário (filtro anaeróbio) em conjunto com a concentração do efluente dos tanques sépticos (Conc.PC1) e, também, possibilita a avaliação da eficiência global do sistema de tratamento em conjunto com a concentração do esgoto bruto (Conc.PC0).

Esse programa de monitoramento contempla a avaliação da eficiência do tratamento primário (EFP) expressão (1); a avaliação da eficiência do 
tratamento secundário (EFS) expressão (2) e a avaliação global do sistema de tratamento (EFG) expressão (3):

$\mathrm{EFP}=(($ Conc.PC0-Conc.PC1 $) /$ Conc.PC0 $) * 100$

$\mathrm{EFS}=(($ Conc.PC1-Conc.PC2 $) /$ Conc. PC1 $) * 100$

$\mathrm{EFG}=($ Conc.PC0 - Conc.PC2 $) /$ Conc. $\mathrm{PC} 0) * 100$

onde:

Conc. $\mathrm{PC} 0$ = concentração do esgoto bruto;

Conc. $\mathrm{PC1}$ = conc. do esgoto na entrada do filtro.

Conc. PC2 = conc. do esgoto na saída do filtro.

\section{RESULTADOS E DISCUSSÃO}

Organiza-se este item em dois blocos, inicialmente, apresenta-se e discute-se o bloco sanitário em seus aspectos de monitoramente e avaliações. Posteriormente apresentam-se as avaliações hidrológicas, que dependem dos dados de avaliação sanitária ou da ETE.

\section{Avaliação sanitária da ETE}

O monitoramento ocorreu de abril de 2002 a maio de 2003. Realizaram-se neste período doze campanhas de coleta de amostras de esgoto na ETE (PC1- entrada e PC2 - saída do filtro) e de água na Sanga da Restinga (PC3 - à montante e PC4 - à jusante do lançamento de efluentes).

Os parâmetros médios encontrados para os parâmetros medidos são apresentados na Tabela 3 .

O sistema de esgoto sanitário opera em regime hidráulico transiente, ou seja, com as vazões variando ao longo do dia. Verificou-se uma vazão reduzida no momento da coleta de amostras na ETE. Para conhecer o volume diário de esgoto tratado na ETE da Vila São Luiz, realizou-se, durante o mês de setembro de 2002, um levantamento no bairro, com o objetivo de determinar o número de domicílios e a população usuária do sistema.

O levantamento permitiu, com base nas contas de água da Companhia Riograndense de Saneamento (CORSAN), determinar o consumo médio per capita de água no valor de 83 1/hab.dia. Adotando-se a contribuição de despejos em $80 \%$ do consumo local de água, conforme a NBR 9649/1986, estima-se então a contribuição per capita em 66,4 l/hab.dia.
Tabela 3 - Valores médios do monitoramento qualitativo

\begin{tabular}{lllll}
\hline Parâmetro & PC1 & PC2 & PC3 & PC4 \\
\hline DBO $(\mathrm{mg} / \mathrm{L})$ & 33,3 & 10,6 & 3,7 & 4,0 \\
DQO (mg/L) & 117,1 & 61,3 & 46,3 & 50,0 \\
ST (mg/L) & 345,8 & 214,8 & 99,8 & 100,3 \\
STS (mg/L) & 62,8 & 23,6 & 36,6 & 42,3 \\
CF (org/100ml) & 213000 & 143600 & 13800 & 15000 \\
\hline
\end{tabular}

Com base na vazão média do esgoto observada no período de monitoramento $(211,97 \mathrm{l} / \mathrm{h})$ e a vazão de esgoto média per capita (66,4 1/hab.dia), utilizou-se duas formas para determinar, a partir dessas vazões, o equivalente populacional, ou seja, a população usuária do sistema:

a) a primeira baseia-se na adoção dos coeficientes de variação da vazão média de água para o esgotamento sanitário: K3=0,5 (coeficiente da hora de menor consumo) assim, a vazão mínima de esgoto pode ser dada pela expressão (4), conforme a NBR 9649/1986:

Qmín=Qméd.K3 = 0,5.Qméd

b) a segunda correlaciona os coeficientes de variação com a população, considerando o amortecimento dos picos de vazão com o tempo de residência na rede, assim, a vazão mínima de esgoto pode ser dada pela expressão (5):

Qmín=Qméd.0,2.P $\mathrm{P}^{0,16}$-Fórmula de Gifft

O equivalente populacional, que representa a estimativa da população usuária do sistema de esgoto sanitário, é apresentado na Tabela 4.

O diagnóstico do sistema de esgoto sanitário apresenta 522 habitantes ligados ao sistema, 282 habitantes que possuem domicílios com ligações parciais e 337 habitantes não ligados ao sistema, sendo a população total do bairro de 1.141 habitantes.

A estimativa da população usuária, baseada na vazão afluente a ETE, difere muito da obtida com o levantamento no bairro. $\mathrm{O}$ que indica que muitos moradores do bairro desconhecem a forma de esgotamento sanitário utilizada em sua residência ou forneceram a informação incorreta de que estavam 
ligados ao sistema, ainda que a Prefeitura Municipal não cobre taxa de esgoto. Desta forma, os moradores não teriam os gastos com a ligação ao sistema (gastos referentes a tubos, caixas de inspeção no interior do lote e mão de obra).

Tabela 4 - Estimativa da população ligada a rede

\begin{tabular}{lll}
\hline Forma de estimativa & População & $\begin{array}{c}\text { \% da } \\
\text { população }\end{array}$ \\
\hline Qmín=0,5.Qméd & 153 pessoas & 13,4 \\
Qmín=Qméd.0,2.P $\mathrm{P}^{0,16}$ & 437 pessoas & 38,3 \\
\hline
\end{tabular}

Obs: com Qméd=2,77 1/hab.h e a vazão média observada no período de monitoramento 211,97 l/h e Qmín, determina-se o equivalente populacional

A situação do baixo percentual de população ligada a rede caracteriza uma realidade recorrente no Brasil. Por um lado tem-se a necessidade de investimento por parte dos moradores nas ligações prediais. Por outro lado esse custo não é reconhecido pela comunidade e, o poder político, por sua vez, não quer se comprometer com a obrigatoriedade de execução dessas obras.

Colaboraria para a solução dessa situação a implantação do instrumento cobrança pelo uso da água bruta conforme prevê a Lei das Águas no Brasil (Lei 9433/1997), visto que a tarifação pelo uso da água forneceria o argumento político para a obrigatoriedade das ligações por parte da comunidade. $\mathrm{O}$ argumento seria o seguinte: se o município não promove as ligações à rede coletora - ele seria penalizado pela cobrança de diluição de efluentes não tratados, o que de forma indireta acabaria onerando a própria comunidade de uma forma geral e por conseqüência, seria socialmente injusto.

Relativo ao balanço de cargas, conforme o equacionamento proposto pelas expressões (1), (2) e (3) determinou-se a eficiência do tratamento primário (EFP), do secundário (EFS) e do global (EFG), para cada uma das 12 campanhas de campo. Logo após foi calculada a média das eficiências das 12 campanhas

A eficiência média na remoção de poluentes apresentou valores satisfatórios para a concepção de tratamento: tanque séptico + filtro anaeróbio com enchimento em pedra + filtro de areia. A NBR 13969/1997 estima para a concepção tanque séptico + filtro de areia, a remoção em termos de DBO, na faixa de 50 a $85 \%$; em termos de DQO, na faixa de 50 a 75\%; em termos de sólidos suspensos, na faixa de 70 a $95 \%$ e para coliformes fecais na ordem de $99 \%$ ou mais.

Tabela 5 - Eficiência média na remoção de poluentes do sistema de tratamento de esgotos, calculada pela média das eficiências das 12 campanhas

\begin{tabular}{llll}
\hline Parâmetro & $\begin{array}{l}\text { EFP } \\
\text { Tanque } \\
\text { séptico }\end{array}$ & $\begin{array}{l}\text { EFS } \\
\text { Filtro } \\
\text { anaeróbio }\end{array}$ & $\begin{array}{l}\text { EFG } \\
\text { Conjunto }\end{array}$ \\
\hline DBO & $66,4 \%$ & $59,8 \%$ & $73,3 \%$ \\
DQO & $76,6 \%$ & $46,3 \%$ & $84,7 \%$ \\
ST & $61,7 \%$ & $32,8 \%$ & $74,0 \%$ \\
STS & $62,3 \%$ & $45,9 \%$ & $72,5 \%$ \\
CF & $89,6 \%$ & $35,4 \%$ & $90,3 \%$ \\
\hline
\end{tabular}

A eficiência na remoção de poluentes é comparável à obtida com o uso de outras formas de tratamento simplificado, tais como: lagoas de estabilização, disposição no solo e reator anaeróbio de manta de lodo, - há exceção na remoção de coliformes fecais - já que os sistemas de lagoas de estabilização e disposição no solo conseguem, normalmente, remoção de coliformes fecais superiores a $99 \%$.

Entretanto esses sistemas de tratamento utilizam rede coletora convencional para condução do esgoto até a ETE, uma vez que conduzem o esgoto bruto.

Para melhorar a qualidade do efluente lançado pelo sistema de esgoto na remoção de coliformes fecais, deve-se estabelecer uma forma de desinfecção do efluente do filtro anaeróbio, que pode ser uma lagoa de polimento.

Com base nos dados de eficiência, verifica-se que o tanque séptico é responsável pela maior parcela na remoção dos poluentes do sistema de tratamento; portanto, deve ser estabelecido pela Prefeitura Municipal um plano de controle (periodicidade da limpeza dos tanques) e de conscientização da população atendida, para que ocorra uma perfeita operação.

Considera-se, assim, que o tanque séptico é o ponto crítico do sistema. Cabe lembrar que a falta de manutenção adequada diminuirá a sua capacidade de retenção de sólidos, o que poderá ocasionar problemas de entupimento na rede e/ou diminuição da eficiência do tratamento.

Recomenda-se, também, que as residências atendidas possuam caixa de gordura para a pia da cozinha. A população deve se conscientizar da necessidade de limpeza periódica dessas caixas. Pelas visitas in loco constata-se que a população não reali- 
za tal manutenção, que é importante para o perfeito funcionamento dos tanques sépticos e da rede coletora.

A eficiência média na remoção de coliformes fecais no filtro anaeróbio foi de $35,4 \%$, sendo essa remoção muito pobre, ocorrendo épocas em ela que foi bem mais reduzida, em $50 \%$ das campanhas de monitoramento a eficiência foi nula. Reduzia-se o índice de coliformes somente quando o filtro apresentava elevado tempo de detenção hidráulica, o que favorecia o decaimento bacteriano. Confirmou-se, por intermédio do monitoramento, a pouca eficiência na remoção de patogênicos pelo filtro anaeróbio.

A título de ilustração, apresenta-se a Figura 7 com as amostras coletadas nos diferentes pontos de controle - PC1, antes do filtro; PC2 depois do filtro; PC3 e PC4, seções a montante e a jusante da efluência da ETE no riacho.

Nesta figura podem ser observados o aspecto e a coloração típica das amostras.

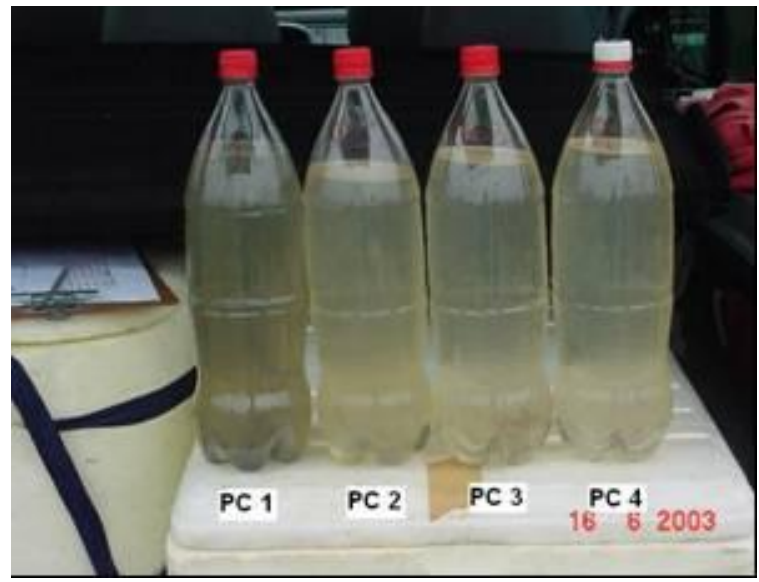

Figura 7 - Amostras coletadas em 16/06/2003.

\section{Avaliações hidrológicas}

Inicialmente, apresentam-se os resultados do monitoramento e, na seqüência, os impactos da implantação do sistema na hidrologia.

Realizou-se o monitoramento quantitativo para um ano de operação do sistema, de abril de 2002 a abril de 2003. Adotou-se as vazões desse período de monitoramento como representativas do escoamento na bacia hidrográfica. O ano de 2002 caracteriza-se como um período chuvoso como demonstrado na Figura 8, na qual são apresentadas as precipitações anuais para o período de 1998 a 2002.

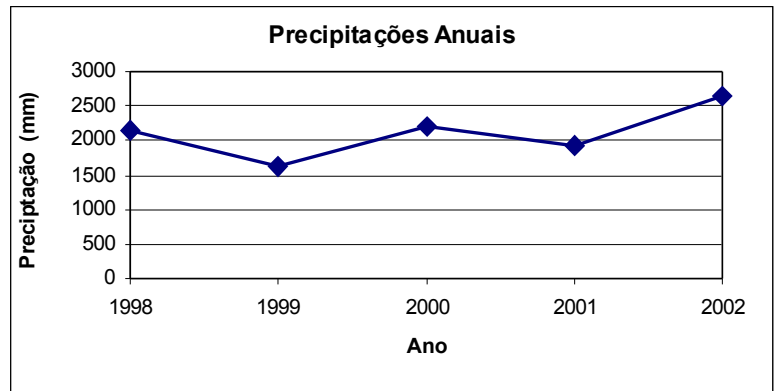

Figura 8. Precipitações anuais 1998-2002

\section{Estação Meteorológica Santa Maria n083936-RS}

A leitura diária do nível de água na calha Parshall (PC5) permitiu a elaboração do fluviograma apresentado na Figura 9, e a obtenção da vazão pela da correlação com a tabela (nível de água na calha $\mathrm{x}$ vazão) obtida em laboratório, conforme as dimensões da calha (medidor de $60 \times 180 \mathrm{~cm}$ ).

Com a visualização do fluviograma percebese a grande variabilidade de vazões que ocorrem na pequena bacia hidrográfica e, também, nota-se a rápida oscilação de nível, provocada por eventos chuvosos em decorrência da reduzida capacidade de armazenamento na bacia.

A calha Parshall implantada permitiu avaliar até a vazão Q25\%, que corresponde a 74,8\% do fluviograma; as vazões superiores foram obtidas pela da correlação da velocidade média com a área da seção transversal.

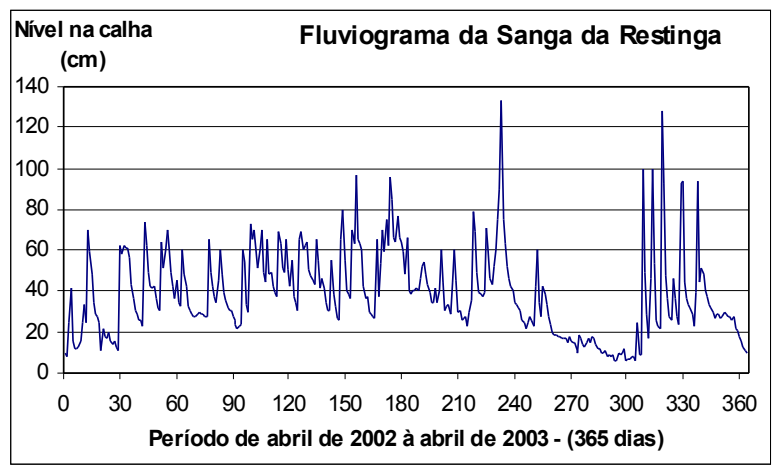

Figura 9 - Fluviograma da Sanga da Restinga

Com esses dados, elaborou-se a curva de permanência de vazões do corpo receptor dos eflu- 
entes do sistema de esgoto sanitário da Vila São Luiz, apresentada na Figura 10.

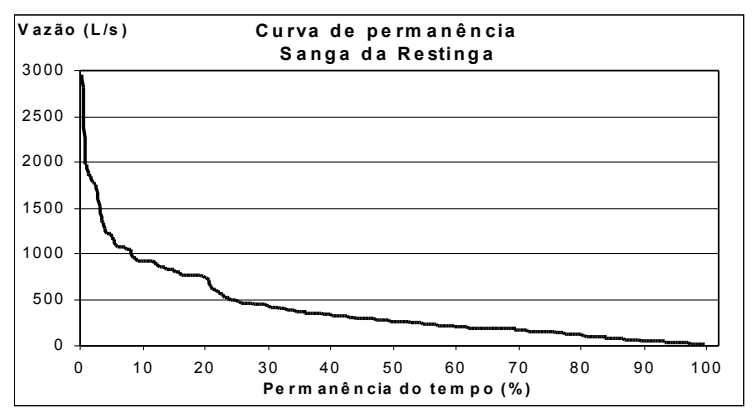

Figura 10 - Curva de permanência

Dessa curva de permanência, extraem-se os dados das vazões de medianas a mínimas, apresentados na Tabela 6 .

Tabela 6 - Permanência de vazões na calha

\begin{tabular}{llll}
\hline $\begin{array}{l}\text { Permanências } \\
\text { de vazões }\end{array}$ & $\begin{array}{l}\text { Vazão } \\
(\mathbf{L} / \mathbf{s})\end{array}$ & $\begin{array}{l}\text { Permanências } \\
\text { de vazões }\end{array}$ & $\begin{array}{l}\text { Vazão } \\
(\mathbf{L} / \mathbf{s})\end{array}$ \\
\hline Q $50 \%$ & 261,00 & Q $75 \%$ & 150,00 \\
Q $55 \%$ & 237,00 & Q $80 \%$ & 121,00 \\
Q $60 \%$ & 202,00 & Q $85 \%$ & 79,00 \\
Q $65 \%$ & 185,50 & Q 90\% & 48,00 \\
Q 70\% & 170,00 & Q 95\% & 30,50 \\
\hline
\end{tabular}

Observa-se que, os valores de vazão encontrados estão na ordem de grandeza dos estimados pelos estudos de regionalização de vazões encontrados para a região - $3 \mathrm{l} / \mathrm{s} . \mathrm{km}^{2}$ para o Q95\% e 26 $\mathrm{l} / \mathrm{s} . \mathrm{km}^{2}$ para a vazão mediana. Ainda, pode-se considerar que, em nível de licença de instalação dos empreendimentos, poderiam ser considerados os valores regionais de vazões, mas em nível de operação do sistema não se poderia prescindir de estimativas mais focadas nos locais dos empreendimentos devido as incertezas naturais dos resultados dos estudos de regionalização hidrológica principalmente em pequenas bacias hidrográficas, Silveira (1997).

A seguir, apresentam-se e discutem-se os resultados de avaliação do impacto no rio segundo as três formas indicadas: $1^{a}$ Forma - Avaliação global da qualidade da água do corpo receptor, antes e após o lançamento dos efluentes.

Utilizou-se o índice de qualidade de água adaptado por COMITESINOS $(1990,1993)$ na forma de produtório, de tal forma que a eventual avaliação desfavorável em qualquer dos oito parâmetros tivesse uma maior repercussão no índice de qualidade da água. A nota média da qualidade da água da Sanga da Restinga, durante o período de monitoramento à montante do lançamento de esgotos (PC3), foi 53 e à jusante do lançamento de esgotos (PC4) foi 50, o que indica uma leve degradação na qualidade da água, ocasionada pela recepção dos efluentes, em vista disso, fica classificada como água de média qualidade.

Verificou-se que, em todas as campanhas, o parâmetro "coliformes fecais" foi o que apresentou menor nota em conseqüência das elevadas concentrações, tanto à montante quanto à jusante do lançamento. $\mathrm{O}$ parâmetro coliforme fecal apresenta o segundo maior peso na composição da nota do índice; portanto foi o parâmetro que mais influenciou o índice de qualidade da água.

$\mathrm{Na}$ Figura 11, pode-se visualizar a variação do índice de qualidade da água ao longo do período de monitoramento. Percebe-se que não ocorrem diferenças significativas em relação à qualidade da água, antes e após o lançamento dos efluentes. Realizando-se uma avaliação global da qualidade da água do rio e verifica-se que ela, conforme o IQA, pode ser classificada de má à média qualidade.

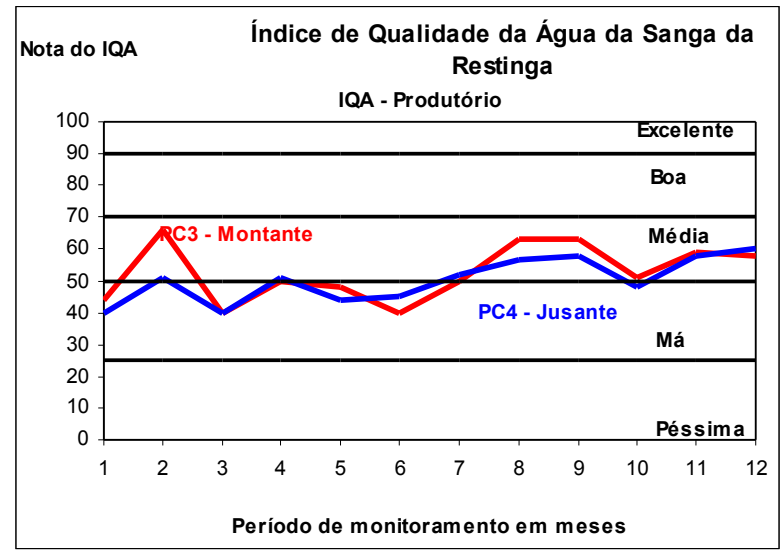

Figura 11 - Índice de qualidade da água no riacho 


\section{$2^{a}$ Forma - Diluição de cargas}

A Tabela 7 apresenta os resultados obtidos com relação à concentração para o parâmetro DBO, para a situação de operação atual e para a situação de operação da ETE, com os limites da Licença de Operação (LO), diluído na variabilidade de vazões do rio. Percebe-se que, para a situação de lançamento dos efluentes nos limites da $\mathrm{LO}$, o parâmetro de DBO situa-se na Classe 3 e 4, para as vazões de diluição de $Q_{50 \%}$ e $Q_{95 \%}$ de permanência no tempo.

Verifica-se, dessa forma, que a adoção de limites para o lançamento de efluentes referentes à carga poluidora dependerá da magnitude das vazões do riacho que recebe as cargas. Portanto, a eficiência do sistema de tratamento deve ser analisada em conjunto com os reflexos no corpo receptor, como já preconiza a nova resolução CONAMA 357, de 17 de março de 2005, em substituição à antiga CONAMA 20/86.

Tabela 7 - Concentração e classes de enquadramento para parâmetro DBO

\begin{tabular}{llllll}
\hline & \multicolumn{2}{l}{ DBO $(\mathrm{mg} / \mathrm{L})$} & \multicolumn{3}{l}{ Classes } \\
& \multicolumn{4}{c}{ CONAMA } \\
\cline { 2 - 6 } & Atual & Limite & Atual & Limite \\
\hline $\mathrm{Q} 50 \%$ & 3,71 & 5,56 & 2 & 3 & \\
$\mathrm{Q} 60 \%$ & 4,80 & 7,16 & 2 & 3 & \\
$\mathrm{Q} 70 \%$ & 5,71 & 8,47 & 3 & 3 & \\
$\mathrm{Q} 80 \%$ & 8,02 & 11,79 & 3 & 4 & \\
$\mathrm{Q} 90 \%$ & 20,20 & 28,27 & 4 & 4 & \\
$\mathrm{Q} 95 \%$ & 31,81 & 42,53 & 4 & 4 & \\
\hline Limites de & DBO: & Clas.1- 3 & $\mathrm{mg} / \mathrm{L} ;$ & Clas.2- & $\mathrm{mg} / \mathrm{L}$; \\
Clas.3- 10 & mg/L; Clas.4 $>10 \mathrm{mg} / \mathrm{L}$. & &
\end{tabular}

Para os outros parâmetros medidos (turbidez, pH, OD, DBO, coliformes totais e fecais), não se observou mudança na situação de enquadramento, durante o período de monitoramento, antes e após o lançamento de efluentes.

O parâmetro oxigênio dissolvido enquadrou-se na Classe 1, em todas as campanhas de monitoramento, tanto à montante quanto à jusante do lançamento de esgoto.

Mesmo tendo a bacia hidrográfica basicamente uma ocupação rural, observam-se índices elevados de coliformes totais e coliformes fecais. Isto pode ser justificado pelo fato de o riacho, na seção em estudo, encontrar-se inserido em meio urbano, entre a Vila São Luiz e a Vila Pelizaro. Nessa região, não existem sistemas de esgotos, apenas ocorrem ligações clandestinas nas galerias de águas pluviais na Vila São Luiz.

\section{$3^{a}$ Forma - Simulação da capacidade de autodepuração do corpo receptor, com o modelo Streeter-Phelps.}

As resoluções CONAMA 20 e 357 dispõem que os limites de DBO estabelecidos para as Classes 2 e 3 poderão ser elevados. Entretanto isso só é possível caso o estudo da capacidade de autodepuração do corpo receptor demonstre que os teores mínimos de OD previstos não serão desobedecidos em nenhum ponto do mesmo, nas condições críticas de vazão $(Q$ crít. $=Q 7,10$, onde $Q 7,10$ é a média das mínimas de 7 (sete) dias consecutivos em 10 (dez) anos de recorrência de cada seção do corpo receptor).

Percebe-se que a realização do estudo da capacidade de autodepuração exige o estudo da adequação de modelos matemáticos e um longo período de monitoramento, que permita obter, além da vazão $Q 7,10$, dados de entrada confiáveis. Em rios ou córregos de pequenas bacias hidrográficas, onde normalmente não existem dados de monitoramento qualitativo e/ou quantitativo, amplia-se essa dificuldade.

No presente estudo, para avaliar a situação do OD, apesar do reduzido período de monitoramento, adota-se o modelo simplificado de StreeterPhelps para inferir sobre a capacidade de autodepuração da riacho, com base tanto no cenário atual quanto no cenário em que a ETE despejasse o efluente no limite da Licença de Operação. Para a simulação, utilizaram-se os parâmetros apresentados no Quadro 1.

As vazões e as concentrações de OD e DBO utilizadas - do rio e da ETE - foram as medidas para a situação de operação atual, e as limites, de acordo com o que foi autorizado pelo órgão ambiental do Estado.

A Tabela 8 apresenta os resultados dessa simulação, obtidos, no que se refere à concentração para o parâmetro de oxigênio dissolvido, no ponto crítico (ponto de menor concentração de oxigênio dissolvido ao longo do percurso do rio) onde ocorre o encontro do riacho em estudo com o Rio VacacaíMirim, - a 3.100 metros à jusante do ponto de lançamento de esgoto. Foram consideradas vazões de diluição o riacho do $Q_{50 \%}$ até o $Q_{95 \%}$ conforme a Tabela 8. 
Quadro 1 - Parâmetros de simulação

\begin{tabular}{|l|l|}
\hline K1 & $\begin{array}{l}\text { coeficiente de desoxigenação, adotado 0,18 } \\
\text { para efluente de tratamento secundário, } \\
\text { conforme Von Sperling }(1996, \text { p.111); }\end{array}$ \\
\hline K2 & $\begin{array}{l}\text { coeficiente de reaeração, adotado 1,15 para } \\
\text { rios rápidos e rasos, conforme Von Sperling } \\
(1996, \text { p.116); }\end{array}$ \\
\hline $\mathrm{v}$ & $\begin{array}{l}\text { velocidade do percurso do rio, 0,15 m/s } \\
\text { velocidade média para vazões de medianas à } \\
\text { mínimas, determinada na Sanga da Restinga; }\end{array}$ \\
\hline $\mathrm{t}$ & $\begin{array}{l}\text { tempo de percurso do ponto de lançamento } \\
\text { de esgotos até o ponto crítico, que é o encon- } \\
\text { tro com o Rio Vacacai Mirim a 3.100 m de } \\
\text { distância, sendo t } 0,24 \text { dia; }\end{array}$ \\
\hline Cs & $\begin{array}{l}\text { concentração de saturação do oxigênio } \\
\text { dissolvido, para a altitude local de 49 m e } \\
\text { temperatura média de 20 C, Cs }=8,97 \\
\text { mg/L; }\end{array}$ \\
\hline OD & $\begin{array}{l}\text { oxigênio dissolvido mínimo permissível de } \\
\text { acordo com os teores mínimos conforme } \\
\text { Res. CONAMA n 20/86. }\end{array}$ \\
\hline
\end{tabular}

Tabela 8 - Concentração de oxigênio dissolvido no ponto crítico do rio

\begin{tabular}{lllcc}
\hline & \multicolumn{2}{c}{ OD $(\mathrm{mg} / \mathrm{L})$} & \multicolumn{2}{c}{ Classes } \\
& \multicolumn{2}{c}{ CONAMA } \\
\cline { 2 - 5 } & Atual & Limite & Atual & Limite \\
\hline Q 50\% & 8,250 & 7,779 & 1 & 1 \\
Q 60\% & 8,249 & 7,644 & 1 & 1 \\
Q 70\% & 8,249 & 7,533 & 1 & 1 \\
Q $80 \%$ & 8,249 & 7,252 & 1 & 1 \\
Q 90\% & 8,247 & 5,857 & 1 & 2 \\
Q 95\% & 8,245 & 4,651 & 1 & 3 \\
\hline
\end{tabular}

Concentração de OD: Classe 1 -> $6 \mathrm{mg} / \mathrm{L}$; Classe 2->

$5 \mathrm{mg} / \mathrm{L}$; Classe 3 - > $4 \mathrm{mg} / \mathrm{L}$ e Classe 4 - > $2 \mathrm{mg} / \mathrm{L}$.

Percebe-se que, para a situação atual, os níveis de OD, no ponto crítico, permanecem praticamente iguais para as diferentes vazões e atendem aos requisitos da Classe 1. Essa situação deve-se ao fato de o lançamento de esgoto, no curso de água, apresentar pequena carga de matéria orgânica

Já para a situação de lançamento de esgoto nos limites da licença de operação, pode-se verificar que, apenas na condição de vazão mímina, $Q_{95 \%}$, a concentração de oxigênio dissolvido no ponto crítico, atenderá aos requisitos de qualidade para a Classe 3. Para as demais condições de vazão, atenderá aos requisitos da Classe 1 e 2 .
Os cálculos permitem inferir que o riacho possui boa capacidade de autodepuração da matéria orgânica, mesmo para a ETE, em que opera com os limites da Licença de Operação. Apenas na condição da vazão mínima, o nível de oxigênio dissolvido no ponto crítico deixa de atender aos requisitos de qualidade para a Classe 2. É necessário, ao município, a continuidade do monitoramento, para confirmar essa expectativa e aprimorar as simulações perante a evolução de ocupação do solo na bacia, tanto no processo urbano como rural.

Este estudo permitiu inferir que os limites de DBO para a Classe 2 e 3 no rio poderiam ser elevados, devido ao atendimento dos limites de OD, mas o curto espaço de tempo de monitoramento e a adoção de um modelo simples indicam somente a possibilidade de aventar a hipótese, a ser confirmada com novos dados e simulações.

\section{CONCLUSÕES E RECOMENDAÇÕES}

Procurou-se por meio deste estudo, avaliar o impacto da implantação de um sistema simplificado de esgotos em um ambiente hidrologicamente desfavorável de pequena bacia, em virtude da natural ocorrência de pequenas vazões de diluição nas estiagens.

A metodologia testada permite avaliar o impacto do lançamento de efluentes, considerando, de forma integrada e em tempo real, a eficiência do sistema de tratamento de esgotos e a repercussão do despejo no exutório de pequena bacia hidrográfica $\left(\mathrm{A}<10 \mathrm{~km}^{2}\right)$.

Com relação ao monitoramento quantitativo do corpo receptor, somente o uso de calha Parshall na pequena bacia hidrográfica permitiu monitorar $75 \%$ do tempo o fluviograma, definindo assim uma solução de baixo custo para sustentar este tipo de proposta de avaliação ambiental integrada.

A eficiência média do sistema de tratamento de esgotos (tanques sépticos + filtro anaeróbio), na remoção de poluentes foi de $73,3 \%$ em termos de DBO; $84,7 \%$ em termos de DQO; $74 \%$ em termos de ST; 72,5\% em termos de STS e 90,3\% em termos de Coliformes Fecais. A exceção dos Coliformes, os resultados apresentam valores satisfatórios para tal concepção de tratamento, conforme a previsão da NBR 13969/1997. Os resultados são comparáveis à eficiência, na remoção de poluentes, obtida com o uso de outras formas de tratamento simplificado, como lagoas de estabilização e disposição no solo. 
O conjunto tanques sépticos e filtro anaeróbio apresenta boa remoção de matéria orgânica e de sólidos, mas verifica-se que o filtro anaeróbio possui baixa capacidade na remoção de coliformes fecais. Recomenda-se que seja acoplada uma forma de desinfecção ao efluente do filtro anaeróbio nesse tipo de sistema.

Com relação à avaliação hidrológica, a partir dos dados medido no local, percebe-se que o lançamento de esgoto no corpo receptor não gerou expressivo impacto, do ponto de vista ambiental, no que se refere aos aspectos quali-quantitativos dos recursos hídricos.

Percebem-se também índices elevados de coliformes totais e fecais à montante do lançamento de esgoto, o que demonstra problemas de saneamento mesmo em bacias com uso predominantemente rural, como foi a do objeto deste estudo.

Os resultados observados evidenciam que, para as vazões de pequena magnitude, ocorre expressiva variabilidade de classe de enquadramento. Com referência à matéria orgânica o parâmetro DBO enquadra-se nas Classes 2 a 4 para as vazões de ocorrência entre Q50\% e Q95\%. A simulação do lançamento do efluente no limite da licença de operação - para o mesmo intervalo de ocorrência de vazões - gerou concentrações situadas entre as classes de enquadramento 3 e 4 ..

Portanto, esse fato corrobora, a partir dos dados do estudo, com o estabelecido pela nova resolução CONAMA. Essa referenda que, para uma compreensão dos impactos, os aspectos qualiquantitativos devem ser tratados em conjunto, por causa da amplitude de variação de vazão na bacia hidrográfica, efeito maximizado ainda mais na pequena bacia hidrográfica.

Como recomendação final, deve-se buscar a participação da comunidade do bairro, através do esclarecimento sobre as vantagens da coleta e tratamento dos esgotos, já que o sistema depende muito da adesão da população para que possa funcionar plenamente.

\section{AGRADECIMENTOS}

Os autores agradecem à Fundação de Amparo à Pesquisa do Estado do Rio Grande do Sul FAPERGS, pelo auxílio recebido; à Prefeitura do Município de Restinga Seca pelo apoio, e aos organismos financiadores de pesquisa CNPq e CAPES pelas bolsas concedidas.

\section{REFERÊNCIAS}

ANDRADE NETO, C. O. (1997). Sistemas Simples para tratamento de esgotos sanitários: experiência brasileira. Rio de Janeiro: ABES, 301p.

APHA; AWWA; WPCF (1995) Standard Methods for the Examination of Water and Wastewater. 19th ed. Washington: American Public Health Association.

ASSOCIAÇÃO BRASILEIRA DE NORMAS TÉCNICAS. (1986) Projeto de redes coletoras de esgoto sanitário: NBR 9649. Rio de Janeiro, set., 10p.

ASSOCIAÇÃO BRASILEIRA DE NORMAS TÉCNICAS. (1993). Projeto, construção e operação de sistemas tanques sépticos: NBR 7229. Rio de Janeiro, set., 28p.

ASSOCIAÇÃO BRASILEIRA DE NORMAS TÉCNICAS. (1997) Tanques sépticos - Unidades de tratamento complementar e disposição final dos efluentes líquidos - Projeto, construção e operação: NBR 13969. Rio de Janeiro, set., 60p.

BRASIL (1986), Resolução CONAMA $n^{\circ}$ 20, Conselho Nacional do Meio Ambiente, Estabelece a classificação das águas doces, salobras e salinas do Território Nacional.

BRASIL (2005), Resolução CONAMA $n^{\circ} 357$, Conselho Nacional do Meio Ambiente, Dispõe sobre a classificação dos corpos de água e diretrizes ambientais para o seu enquadramento, bem como estabelece as condições e padrões de lançamento de efluentes, e dá outras providências.

CETESB. (1987). Companhia de Tecnologia de Saneamento Ambiental - São Paulo. Guia de Coleta e preservação de amostras de água. São Paulo: CETESB, 150p.

COMITESINOS. (1990) Utilização de um Índice de Qualidade da Água para o Rio dos Sinos/RS. Porto Alegre; COMITESINOS, 33p.

COMITESINOS. (1993) Aplicação de um Índice de Qualidade da Água no Rio dos Sinos. Porto Alegre; DMAE, 59p.

CYNAMON, S. E. (1986) Sistema não Convencional de Esgoto Sanitário a Custo Reduzido para Pequenas Coletividades e Áreas Periféricas. Publicação da Escola Nacional de Saúde Pública, Fundação Osvaldo Cruz - FIOCRUZ. Rio de Janeiro RJ. 2a edição.

FEPAM/RS (2002). Fundação de Proteção Ambiental Henrique Luís Roessler/RS. Licença de opera- 
ção LO n. 838/2002-DL. Sistema de esgoto sanitário da Vila São Luiz, constituído de rede coletora e estação de tratamento de esgoto. Restinga Seca/RS.

GASTALDINI, M. C. C. \& TEIXEIRA, E. C. (2001) Avaliação da qualidade da água. In: PAIVA, J. B. D. de \& PAIVA, E. M. C. de (Orgs). Hidrologia aplicada à gestão de pequenas bacias hidrográficas. Porto Alegre: ABRH, p. 453-482.

IBGE (2000). Instituto Brasileiro de Geografia e Estatística. www.ibge.net/home/estatistica/

MINISTÉRIO DO EXÉRCITO (1980) Restinga Seca/RS. Folha SH.22-V-C-V-3. Escala 1:50.000, Diretoria de Serviço Geográfico - DSG.

populacao/condicaodevida/pnsb/default.shtm

PROSAB (2002). Programa de Pesquisas em Saneamento Básico. www.finep.gov.br/prosab/ esgo to.htm.

REETZ, E. F. (2002) Avaliação quali-quantitativa dos recursos hídricos superficiais na bacia hidrográfica do campus da Universidade Federal de Santa Maria. 129f. Dissertação de Mestrado em Recursos Hídricos e Saneamento Ambiental, UFSM.

SILVEIRA, G. L. (1997) Quantificação de Vazão em Pequenas Bacias Hidrográfica com Dados Escassos, Tese de Doutorado em Engenharia de Recursos Hídricos e Saneamento Ambiental, $\mathrm{IPH}$, Universidade Federal do Rio Grande do Sul.

SILVEIRA, G. L. ; TUCCI, C. E. M. ; SILVEIRA, A. L. L. (1998) Quantificação de Vazão em Pequenas Bacias sem Dados, Revista Brasileira de Recursos Hídricos, Vol. 3, N.3, jul/set, p. 111-131.

SILVEIRA, G. L.; TUCCI, C. E. M, (1998) Monitoramento em pequenas Bacias para a Estimativa de Disponibilidade Hídrica Revista Brasileira de Recursos Hídricos, Porto Alegre RS, v. 3, n. 3, p. 97-110.

VON SPERLING, M. (1996) Introdução à Qualidade das Águas e ao Tratamento de Esgotos. Belo Horizonte: Departamento de Engenharia Sanitária e Ambiental; Universidade Federal de Minas Gerais: 2a edição, 243p.
Environmental Assessment of a Simplified Sewer System

\section{ABSTRACT}

Sewer services for small communities should be associated with low implementation and operational costs, and final disposal of the effluent should not pollute the sources. This article presents an environmental impact survey of the use of a simplified sewer system. Sanitation efficiency and hydrological aspects are assessed concerning qualitative and quantitative alterations in the flow to the receiving body of water. The Cynamon system was evaluated. This system services a low-income community with a population of around 2000 inhabitants in a small watershed environment with a drainage area of $9.6 \mathrm{~km} 2$ in the section receiving the liquid effluent. In terms of sanitation, there was a $74 \%$ removal of BOD and total solids, which is considered adequate. There was a $90 \%$ removal of coliforms, which is considered a very poor result. In hydrological terms, even taking into account the unfavorable situation of the small basin, with the occurrence of lower specific median and minimum outflows as compared to larger basins, the effluent loads throughout the system did not lead to quality degradation in the run-off to the receiving body of water. The system is feasible even considering the unfavorable situation of low flow into the receiving body. A final treatment of the effluent liquid is recommended by means of maturation lagoons for greater efficiency in the removal of coliforms.

Key-words: simplified sewer system, low flow, water resources management. 